\title{
APATITE, MONAZITE AND ALLANITE; THREE RARE EARTH MINERALS FROM KORSNÄS, FINLAND
}

\author{
Heikni Papunen and O. Lindsjö
}

\begin{abstract}
Papunen, Heikkr and Lindsjö, O., 1972: Apatite, monazite and allanite; three rare earth minerals from Korsnäs, Finland. Bull. Geol. Soc. Finland 44, $123-129$.
\end{abstract}

In the RE-bearing lead deposit of Korsnäs, apatite is the most common $R E$ mineral, monazite is a widespread accessory and allanite is a rare constituent. The paper describes one type of each. Also, the physical properties and chemical composition of the minerals are presented. The chemical analyses contain determinations of the main components, trace elements and distribution of the rare earths. Light rare earths abound in each mineral, but slight differences can be observed in fractionation.

Heikki Papunen, Institute of Geology and Mineralogy, University of Turku, 20500 Turku 50, Finland.

O. Lindsjö, Central Laboratory, Outokumpu Company, 28330 Pori 33, Finland.

\section{Introduction}

The Korsnäs lead deposit is situated in the western coastal area of Finland about $30 \mathrm{~km}$ south of Vaasa. The deposit, which has earlier been described e.g. by Nykänen (1960) and Tuominen (1961), is a heterogeneous body in a strongly sheared zone containing pegmatitic and calcareous skarn host rocks. In addition to lead, an $R E$-bearing apatite concentrate has also been produced at the mine. Korsnäs is famous for its rare minerals in crystal forms of which apophyllite (Sahama 1965), harmotome (Sahama and Lehtinen 1967) and baryte (Papunen 1968) have been described. Exploitation has brought to light that several of the minerals of the mine contain minor amounts of rare earths. This study describes the three principal $R E$ minerals, apatite, monazite and allanite. It is evident that, taking the deposit as a whole, some mineralogical variation exists among the mentioned minerals. The described samples are thus considered as single examples, not as representatives of the whole species.

\section{Apatite}

Apatite is one of the main minerals of the deposit. It occurs as different types in skarns and other calcareous host rocks. Idiomorphic crystals have been encountered in several places. 
However, unlike many other minerals, it only very seldom exists as crystal druses in cavities.

The apatite of this study was collected from soft moulded skarn fragments in the limestone located on the +50 level (drift 4 ) of the mine. The skarn fragments were up to $1 \mathrm{~m}$ in size and were altered into chlorite-rich soft mould, which contained idiomorphic crystals as hard remnants in the lower parts of the fragments. In addition to fine-grained galena and pyrite the crystals were mainly apatite and monazite.

The apatite shows typical hexagonal crystal forms with well developed hexagonal prisms, but the bipyramides or basal pinacoides can only be seen in exceptional cases. Instead, basal parting is extensive in most of the crystals. The surfaces are rough and full of small irregular or roundish pits. The lengths of the prisms collected varied from 1 to $20 \mathrm{~mm}$. The mineral is greenish-gray and turbid. Under a microscope it shows numerous minute inclusions which evidently cause the turbidity. Of the inclusion minerals, the galena and pyrite crystals are wellidentified as are also calcite and a serpentine-like sheet silicate. Most inclusions are, however, too small for identification.

The refractive indices are: $\omega=1.639$ and $\varepsilon=1.634 \pm 0.001$. The cell edges, which were determined by $\mathrm{X}$-ray goniometer with quartz as the internal standard are: $a_{0}=6.900 \pm 0.003 \AA$ and $c_{0}=6.900 \pm 003 ; c: a=0.734$.

Although the apatite was purified by a heavy liquid separation for the mineral analysis, the final fraction still contained foreign minerals. The chemical composition presented in Table 1 reflects this low purity, because the $\mathrm{SiO}_{2}, \mathrm{CO}_{2}$, $\mathrm{Pb}$ and $\mathrm{S}$ figures are anomalously high. To evaluate the positions of the $\mathrm{Si}$ and $\mathrm{C}$-atoms the formula was calculated on the basis of $10 \mathrm{Ca}, R E$ and other replacing atoms (Deer et al. 1962). Since now the P-figure alone is close to 6 it seems that the $\mathrm{C}$ - and $\mathrm{Si}$-atoms originate from the inclusion minerals. Of the trace elements, the atomic amounts of $\mathrm{Pb}$ and $\mathrm{S}$ are almost equal and also evidently originate from the inclusion

galena. The almost equal figures for the $\mathrm{F}$ and $\mathrm{OH}$ groups in the formula indicate that the apatite is halfway between hydroxyl- and fluorapatites.

TABLE 1.

Chemical composition of apatite. Analyzed by O. Lindsjö

Main components

$\left.\mathrm{Fe}_{2} \mathrm{O}_{3}^{*}\right) \ldots \quad 0.73$

$\mathrm{Al}_{2} \mathrm{O}_{3} \ldots \ldots \quad 0.13$

$\begin{array}{lll}\mathrm{MgO}^{2} & \ldots .25\end{array}$

$\mathrm{CaO} \ldots \ldots .46 .6$

SrO ...... 0.40

$\mathrm{Na}_{2} \mathrm{O} \quad \ldots \quad 0.56$

$\left.\Sigma R E_{2} \mathrm{O}_{3}^{* *}\right) \quad 6.16$

$\mathrm{P}_{2} \mathrm{O}_{5} \ldots \ldots \quad 37.7$

$\begin{array}{llll}\mathrm{SiO}_{2} & \ldots & 1.25\end{array}$

$\mathrm{CO}_{2} \ldots \ldots \quad 1.74$

$\mathrm{H}_{2} \mathrm{O} \ldots \ldots \quad 1.0$

$\mathrm{F} \ldots \ldots \ldots \quad 1.8$

Total 98.33

Trace elements

$\mathrm{K}_{2} \mathrm{O} \ldots \ldots$

0.025

$\mathrm{Cr}_{2} \mathrm{O}_{3} \ldots \ldots \quad 0.013$

$\mathrm{MnO} \ldots . .0 .060$

$\mathrm{CoO} \ldots . . .0003$

$\mathrm{NiO} \ldots . . .0004$

$\mathrm{CuO} \ldots . .0004$

$\mathrm{ZnO} \ldots . . .00000000$

CdO ..... 0.006

$\begin{array}{lll}\mathrm{SnO} & \ldots . . & 0.027\end{array}$

$\mathrm{PbO} \ldots . . .1 .2$

$\mathrm{Sb}_{2} \mathrm{O}_{3} \ldots \ldots \quad 0.018$

$\mathrm{Bi}_{2} \mathrm{O}_{3} \ldots \ldots \quad 0.061$

$\mathrm{U}_{3} \mathrm{O}_{8} \ldots \ldots \quad 0.060$

$\mathrm{S} \ldots \ldots \ldots \ldots 0.28$

Total 1.803

Sum of the analysis 100.133
Number of ions on the basis of 10
(Ca, RE..)

$\mathrm{Fe} 0.101$ Theo-

Al .... $0.028 \quad 0 \quad \begin{array}{r}\text { retical } \\ \text { formula }\end{array}$

$\begin{array}{lll}\mathrm{Mg} & \ldots . & 0.068\end{array}$

$\mathrm{Ca} \ldots \ldots \quad 9.150 \quad 10.00 \quad 10$

$\mathrm{Sr} \ldots \ldots \quad 0.043$

$\mathrm{Na} \ldots \ldots .0 .201$

RE ... 0.409

P .... 5.810

Si $\ldots \ldots .0 .227\} 6.47 \quad 6$

C .... 0.432 (

$\mathrm{OH} \ldots \ldots \quad 1.217$

F $\ldots \ldots$

$\mathrm{O} \ldots \ldots$

1.0362 .252

$24.89524 .90 \quad 24$

Distribution of the rare earths

$\Sigma R E_{2} \mathrm{O}_{3}=6.16$ wt \%

$\mathrm{Sc}_{2} \mathrm{O}_{3} \quad \cdots \quad-$

$\mathrm{Y}_{2} \mathrm{O}_{3} \ldots 2.9$

$\mathrm{La}_{2} \mathrm{O}_{3} \quad \ldots \quad 14.3$

$\mathrm{CeO}_{2} \ldots 40.0$

$\mathrm{Pr}_{6} \mathrm{O}_{11} \ldots 7.5$

$\mathrm{Nd}_{2} \mathrm{O}_{3} \ldots 24.5$

$\mathrm{Sm}_{2} \mathrm{O}_{3} \ldots \quad 4.3$

$\mathrm{Eu}_{2} \mathrm{O}_{3} \ldots \quad 0.96$

$\mathrm{Gd}_{2} \mathrm{O}_{3} \ldots \quad 2.4$

$\mathrm{Tb}_{4} \mathrm{O}_{7} \ldots \quad 0.21$

$\mathrm{Dy}_{2} \mathrm{O}_{3} \ldots \quad 0.75$

$\mathrm{Ho}_{2} \mathrm{O}_{3} \ldots \quad 0.12$

$\mathrm{Er}_{2} \mathrm{O}_{3} \ldots \quad 0.18$

$\mathrm{Tm}_{2} \mathrm{O}_{3}$. 0.020

$\mathrm{Yb}_{2} \mathrm{O}_{3} \ldots \quad 0.081$

$\mathrm{Lu}_{2} \mathrm{O}_{3} \ldots-$

\begin{tabular}{rr}
$\mathrm{ThO}_{2} \cdots$ & 1.16 \\
\hline Total & 99.381
\end{tabular}

*) $\mathrm{Fe}_{2} \mathrm{O}_{3}=$ total $\mathrm{Fe}$ as $\mathrm{Fe}_{2} \mathrm{O}_{3}$

**) $\Sigma R E_{2} \mathrm{O}_{3}$ includes all the rare earths as well as $\mathrm{Sc}, \mathrm{Y}$ and $\mathrm{Th}$

\section{Monazite}

Monazite is a common accessory mineral of the deposit. It generally exists as very small crystals and becomes apparent only by mineral separation of the samples.

The monazite described here was collected from the same soft skarn mould on the $+50 \mathrm{~m}$ level of the mine as the apatites mentioned above. These monazite crystals ranged in size from $0.5 \mathrm{~mm}$ to $3 \mathrm{~mm}$. They often had rough 
surfaces, but, in addition, some well-formed crystals were also found. The crystals are elongated in the b-axis direction and usually slightly flattened parallel to (100). The following crystal forms were recorded in well-formed crystals: (100) (101) (110) (010) and (101).

The mineral is yellow-brown, and the grains are fresh and clear. The cleavages along (100) and (010) are only rarely to be seen in thin section suggesting that the mineral is not altered (Molloy 1959). The refractive indices presented in Table 3 were measured by an immersion method with high refractive liquids, 2V by Mallard's method (Bloss 1961) and the specific gravity by a pycnometer with toluene as a reference liquid. The cell dimensions were determined from precession photographs.

\section{TABle 2.}

Chemical composition of monazite. Analyzed by O. Lindsjö

Main components

$\mathrm{CaO} \ldots \ldots \quad 0.63$

$\left.\mathrm{Fe}_{2} \mathrm{O}_{3}{ }^{*}\right) \ldots 0.33$

$\mathrm{MgO} \quad \ldots \quad 0.23$

$\mathrm{Na}_{2} \mathrm{O} \quad \ldots \quad 0.24$

$\mathrm{Al}_{2} \mathrm{O}_{3} \ldots . \quad 0.28$

$\mathrm{PbO} \ldots \ldots \quad 0.27$

$\left.\Sigma R E_{2} \mathrm{O}_{3}^{* *}\right) \quad 69.88$

$\mathrm{P}_{2} \mathrm{O}_{5} \ldots \ldots 25.7$

$\mathrm{SiO}_{2} \ldots \ldots \quad 2.60$

Total 100.16 \begin{tabular}{lll} 
Trace elements & \\
$\mathrm{Li}_{2} \mathrm{O}$ & $\ldots$ & 0.002 \\
$\mathrm{~K}_{2} \mathrm{O}$ & $\ldots$ & 0.01 \\
$\mathrm{SrO}$ & $\ldots$ & 0.10 \\
$\mathrm{BaO}$ & $\ldots$ & 0.052 \\
$\mathrm{~V}_{2} \mathrm{O}_{5}$ & $\ldots$ & 0.032 \\
$\mathrm{MnO}$ & $\ldots$ & 0.010 \\
$\mathrm{NiO}$ & $\ldots$ & 0.006 \\
$\mathrm{CuO}$ & $\ldots$ & 0.003 \\
$\mathrm{ZnO}_{n}$ & $\ldots$ & 0.045 \\
$\mathrm{CdO}_{2}$ & $\ldots$ & 0.001 \\
$\mathrm{Sb}_{2} \mathrm{O}_{3}$ & $\ldots$ & 0.043 \\
$\mathrm{Bi}_{2} \mathrm{O}_{3}$ & $\ldots$ & 0.030 \\
$\mathrm{U}_{3} \mathrm{O}_{8}$ & $\ldots$ & 0.007 \\
\hline & Total & 0.341
\end{tabular}

Sum of the analysis: 100.501
Number of ions on the basis of $16 \mathrm{O}$

Ca 105) Theo-

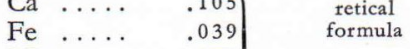

$\mathrm{Mg} \mathrm{\ldots ...053}$

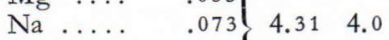

Al .....

$\mathrm{Pb} \ldots \ldots$

.051

.011

$R E \quad \ldots \quad 3.975$

$\left.\begin{array}{rrr}\mathrm{P} & \ldots \ldots & 3.392 \\ \mathrm{Si} & \ldots \ldots & .405\end{array}\right\} 3.80 \quad 4.0$

Distribution of the rare-earths

$\left.\Sigma R E_{2} \mathrm{O}_{3}{ }^{* *}\right)=69.88 \mathrm{wt}=\%$

$\mathrm{Sc}_{2} \mathrm{O}_{3} \quad \cdots \quad-$

$\mathrm{Y}_{2} \mathrm{O}_{3} \ldots \quad 0.2$

$\mathrm{La}_{2} \mathrm{O}_{3} \ldots 26.6$

$\mathrm{CeO}_{2} \ldots 4.4$

$\mathrm{Pr}_{6} \mathrm{O}_{11} \ldots \quad 5.6$

$\mathrm{Nd}_{2} \mathrm{O}_{3} \ldots 16.4$

$\mathrm{Sm}_{2} \mathrm{O}_{3} \ldots \quad 1.7$

$\mathrm{Eu}_{2} \mathrm{O}_{3} \ldots \quad 0.30$

$\mathrm{Gd}_{2} \mathrm{O}_{3} \ldots \quad 0.62$

$\mathrm{Tb}_{4} \mathrm{O}_{7} \ldots \quad 0.06$

$\mathrm{Dy}_{2} \mathrm{O}_{3} \ldots \quad 0.091$

$\mathrm{Ho}_{2} \mathrm{O}_{3} \ldots \quad 0.017$

$\mathrm{Tr}_{2} \mathrm{O}_{3} \mathrm{O}_{3} \cdot-$

$\mathrm{Yb}_{2} \mathrm{O}_{3} \ldots 0.003$

$\mathrm{Lu}_{2} \mathrm{O}_{3} \ldots-$

$\frac{\mathrm{ThO}_{2} \cdots}{\text { Total } 100.211}$

*) $\mathrm{Fe}_{2} \mathrm{O}_{3}=$ total $\mathrm{Fe}$ as $\mathrm{Fe}_{2} \mathrm{O}_{3}$

**) $\Sigma R E_{2} \mathrm{O}_{3}$ includes all the rare earths and $\mathrm{Sc}, \mathrm{Y}$ and $\mathrm{Th}$.
TABLE 3.

Monazite, Korsnäs

cell dimensions: monoclinic

$a_{0}=6.475 \AA \pm 0.005 \AA$
$b_{0}=6.997 \AA$
$c_{0}=6.777 \AA$
$\beta=76^{\circ} 40^{\prime}$

axial ratio: $a: b: c=0.925: 1: 0.969$

refractive indices:

$\alpha=1.792 \quad \beta=1.800 \quad \gamma=1.840 \pm 0.003$
$2 \mathrm{~V} \gamma=11^{\circ} \pm 0.5^{\circ}$

Density: $D=5.23 \mathrm{~g} / \mathrm{cm}^{3}$

optic orientation:

$\alpha \Pi \mathrm{b} \quad$ optic axial plane is perpendicular to $(010)$

$\beta \Lambda \mathrm{a}=7^{\circ}$

$\gamma \Lambda \mathrm{c}=6^{\circ}$

The chemical composition and the calculated formula (Table 2) indicate a slight excess of $R E$ and replacing atoms and a deficiency of $\mathrm{P}+\mathrm{Si}$. Si seems to replace $\mathrm{P}$ in the monazite because the inclusion silicates are rare in the analyzed crystals.

The amount of Th is low, $0.15 \%$, and the mineral thus belongs to the group of (almost) thorium-free monazites. The order of distribution of the rare earths is as follows: $\mathrm{Ce}>\mathrm{La}>$ $\mathrm{Nd}>\mathrm{Pr}>\mathrm{Sm}$, which according to Deer et al. (1962) holds true for most monazites.

\section{Allanite \\ Occurrence}

During the exploration of the deposit a black mineral was found in drill core KR 214 on a deep level $(358.1 \mathrm{~m})$. On closer examination the mineral proved to be allanite. Later on, the same species was also met with occasionally among the carbonate minerals in some other localities of the deposit. The mineral described is from the forementioned drill core.

The allanite-bearing rock is a skarn which also contains pale green diopside, tremolite and calcite as main minerals. Sphene is the most common of the accessories, quartz is rare as are 
also sulfides, galena and pyrite, which occur as irregular specks in the calcite. About 50 vol percent of the sample is allanite. It seems almost black with the naked eye and its lustre resembles that of the metallic oxides. It occurs as laths elongated in the direction of the b-axis and measures up to $25 \mathrm{~mm}$ in length and $1.5 \mathrm{~mm}$ in diameter. The allanite prisms are intersected by diopside, tremolite and occasionally also by calcite grains. The crystal form of allanite, mainly (101), is visible only in exceptional cases. The allanite is pure without any pigmenting matter. The only inclusions are the rare small liquid-gas inclusions ranging in size from 1 to $5 \mu$.

\section{Physical properties}

In thin section the mineral is pleochroic with $\alpha=$ light brown $\beta=$ brown, $\gamma=$ greenish brown and the absorption $\alpha<\beta<\gamma$. The extinction is not even and the extinction angle varies slightly in different parts of the same grain as does also the birefricence. The refration indices measured by the immersion method proved to be:

$$
\alpha=1.738 \quad \beta=1.744 \quad \gamma=1.753 \pm 0.001
$$

and the birefricence $\gamma-\alpha=0.015$. The birefricence was also measured by a Berek compensator from a thin section $(0.11 \mathrm{~mm}$ thick) before and after the heat treatment. After heating for 6 hours at $750^{\circ} \mathrm{C}$, the birefricence increased about $10 \%$ (12\% was the mean of three determinations). The brown color of the mineral also deepened evidently due to the oxidation of the iron, but it seems that the heating also caused perfection of the lattice and increased the birefricence. Thed ensity, measured by a pycnometer, was $3.69 \mathrm{~g} / \mathrm{cm}^{3}$ before and $3.82 \mathrm{~g} / \mathrm{cm}^{3}$ after the heat treatment.

The lattice parameters were measured by a Weissenberg single crystal method using a calibrated copper wire as standard. The parameters as well as the d-values of unheated
TABLE 4.

Crystal data of Korsnäs allanite

Cell dimensions (unheated):

monoclinic

$a_{0}=10.145 \pm 0.005 \AA$
$b_{0}=5.70 \pm 0.01 \AA$

$\beta \quad=114^{\circ} 36^{\prime}$

$V_{0}=469.8 \AA^{3}$

$c_{0}=8.936 \pm 0.005 \AA \quad a: b: c=1.780: 1: 1.568$

$d$-values (Wide angle diffraction goniometer, chart speed $1 / 2 \% \mathrm{~min}$, Fe-rad, Si internal standard)

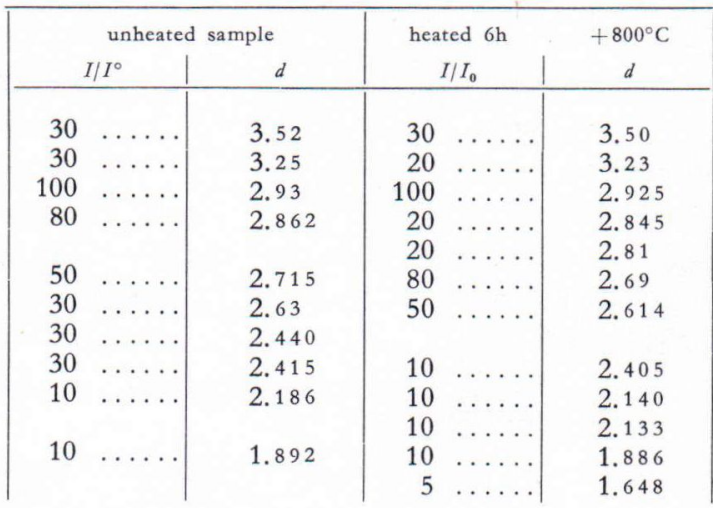

samples are presented in Table 4. Heating brought about a slight reduction in the lattice dimensions, which agrees with the observation of increasing density. Thus, it seems that, although the mineral is metamictic, it is only faintly so, because the transformations of the physical constants during heating are slight.

\section{Chemical composition}

The chemical composition of allanite is presented in Table 5. The mineral was separated by a Clerici solution with the result that the foreign minerals in the analyzed sample did not exceed 0.3 volume percent. According to Hasegava (1960), the formula of allanite in generalized form is:

$\left(\mathrm{Ca}_{2-\mathrm{n}} \mathrm{Ce}_{\mathrm{n}}\right)_{2}\left(\mathrm{Fe}_{\mathrm{n}}^{+2} \mathrm{Fe}_{1-\mathrm{n}}^{+3}\right)\left(\mathrm{Fe}_{\mathrm{m}}^{+3} \mathrm{Al}_{2-\mathrm{m}}\right)_{2} \mathrm{Si}_{3} \mathrm{O}_{12}$ $(\mathrm{OH})$

The oxidation state of iron was not determined for the allanite described here, so that the $m$ and $\mathrm{n}$ values of the forementioned formula cannot be 
TABLE 5.

Chemical composition of allanite. Analyzed by O. Lindsjö

Main components

\begin{tabular}{lcc} 
& & wt $\%$ \\
$\mathrm{SiO}_{2} \ldots \ldots$ & 34.9 \\
$\mathrm{TiO}_{2}$ & $\ldots \ldots$ & 0.17 \\
$\mathrm{Fe}_{2} \mathrm{O}_{3} *$ & $\ldots$ & 9.6 \\
$\mathrm{Al}_{2} \mathrm{O}_{3}$ & $\ldots$ & 18.0 \\
$\mathrm{Cr}_{2} \mathrm{O}_{3}$ & $\ldots$ & 0.89 \\
$\mathrm{CaO}$ & $\ldots \ldots$ & 12.6 \\
$\mathrm{SrO}$ & $\ldots \ldots$ & 0.87 \\
$\mathrm{MgO}$ & $\ldots$ & 2.0 \\
$\mathrm{MnO}$ & $\ldots$ & 0.26 \\
$\sum R E_{2} \mathrm{O}_{3} * *$ & 19.20 \\
$\mathrm{H}_{2} \mathrm{O}$ & $\ldots \ldots$ & 1.65 \\
\hline
\end{tabular}

*) $\mathrm{Fe}_{2} \mathrm{O}_{3}=$ total $\mathrm{Fe}$ as $\mathrm{Fe}_{2} \mathrm{O}_{3}$

**) includes all the rare earths and $\mathrm{Sc}, \mathrm{Y}$ and $\mathrm{Th}$
Number of ions on the basis of $13(\mathrm{O}, \mathrm{OH})$

Theo-
retical
formula

Si $\ldots \ldots \ldots 3.086 \quad 3.09 \quad 3.0$

$\mathrm{Fe} \ldots \ldots \ldots 0.639$

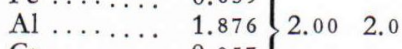

$\mathrm{Cr} \ldots \ldots$

$\mathrm{Mg} \ldots \ldots .0 .264)$

Ti ...... 0.011$\} 0.85 \quad 1.0$

$\mathrm{Fe} \ldots \ldots \ldots(0.52)$

$\mathrm{Ca} \ldots \ldots .1 .194$

Sr ...... 0.045

$\mathrm{Mn} \ldots 0_{0.020} 1.88 \quad 2.0$

$R E \ldots \ldots, 0.622$

$\begin{array}{lllll}\mathrm{H} & \ldots \ldots & \ldots .974 & 0.97 & 1.0\end{array}$

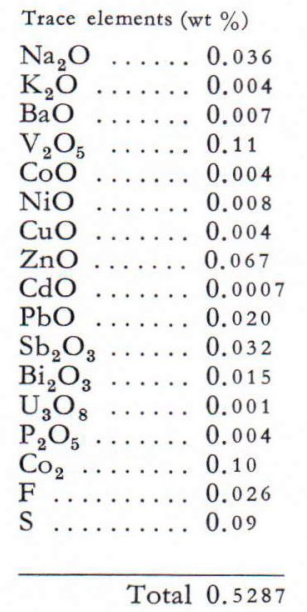

Sum of the analysis: 100.6687

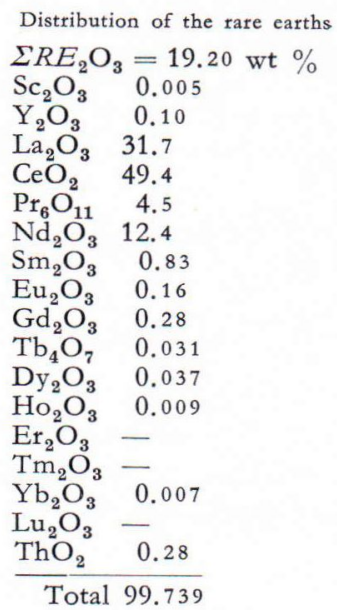

directly determined. They can be calculated, however, from the number of $\mathrm{Al}$ and $R E$-ions presented in Table 5. The amount of $\mathrm{Al}+\mathrm{Cr}$ gives a value of 0.13 for $\mathrm{m}$ and that of $R E$ atoms gives 0.62 for $\mathrm{n}$. The number of atoms on the basis of $13(\mathrm{O}, \mathrm{OH})$ agrees very welı with the formula of Hasegava (1960). The magnesiumcontent of the Korsnäs allanite is considerably higher than that reported e.g. by Deer et al. (1962) for allanites in general. However, Geijer (1927) reports a magnesium orthite from Norberg, Sweden, which contains up to $14.5 \% \mathrm{MgO}$. The Korsnäs allanite seems to be a member of an allanite to magnesian allanite series. It is also possible that this solid solution is complete as proposed by Winchell and Winchell (1959).

\section{Distribution of the rare earths}

The abundances of the different rare earths are presented in Tables 1, 2 and 5. During the analytical procedure the rare earth group was separated and the different elements were

determined from the $R E$ precipitate by atomic absorption spectroscopy with the exception of Ce and Th, which were determined photometrically. The abundances are presented as weight percentages from the sum of the whole precipitate (Kinnunen and Lindsjö 1967).

Fig. 1, which depicts the abundances of the elements, indicates that the Oddo-Harkins rule holds true for each sample. The light rare earths abound in all of the minerals. Slight differences exist, however, in fractionation. The relative abundances presented in Fig. 2 show that the apatite contains a slight excess of heavy rare earths in respect to monazite and especially to allanite. The fractionation may be dependent on the prevailing $\mathrm{P}-\mathrm{T}$ conditions during crystallization, but the determination of the relations needs further analytical and synthetic studies.

Acknowledgements - The authors are indebted to Professor P. Haapala of the Outokumpu Co for permission to publish this paper, to Mr Y. Vuorelainen for the mineral samples as well as to Mr T. Huhtala, M. A. and Miss Ritva Heikkilä for their help in the mineralogical determinations. 

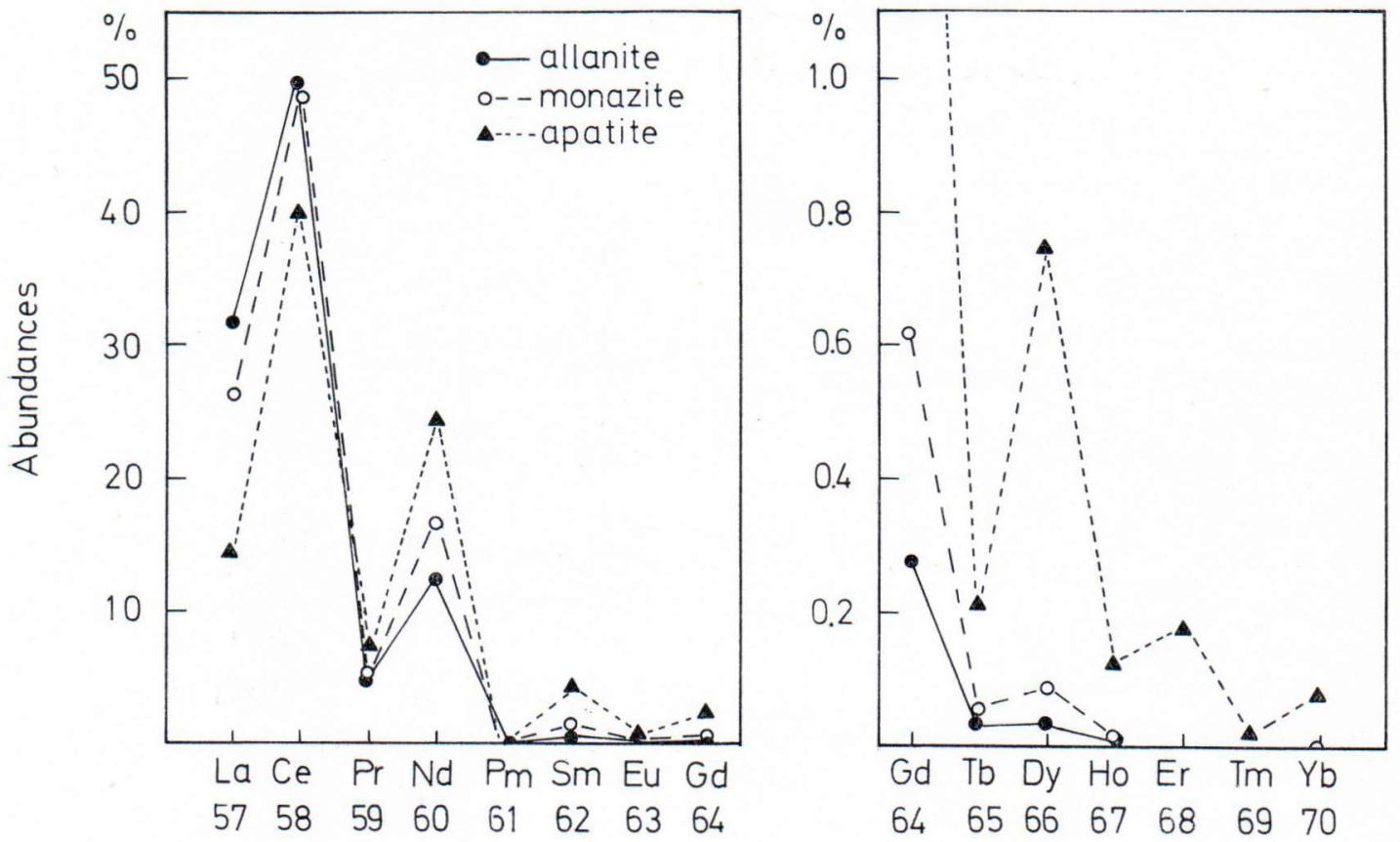

Frg. 1. Distribution of rare earths between the allanite, monazite and apatite of Korsnäs. The total sum of $\mathrm{RE}_{2} \mathrm{O}_{3}$ has been calculated as $100 \%$.

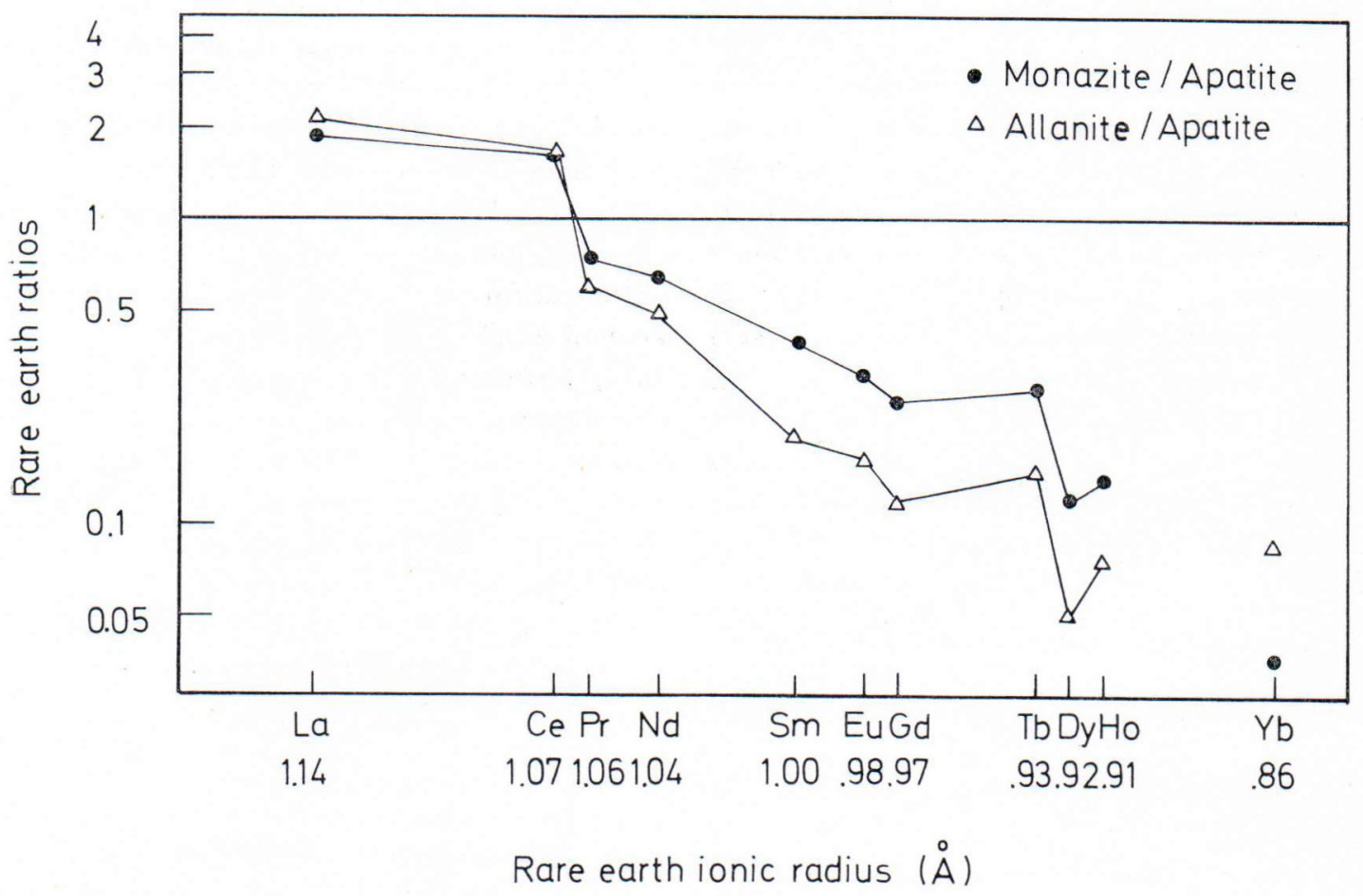

FIG. 2. The relative abundances of different rare earth elements in the monazite and allanite in respect to apatite. 


\section{REFERENCES}

Bloss, Donald F. (1961) An introduction to the methods of optical crystallography. Holt, Rinehart and Winston, New York.

Deer, W. A., Howie, R. A. and Zussman J. (1962) Rock forming minerals Vol. 1 and Vol. 4. Longmans, London.

Geijer, Per (1927) Some mineral association from the Norberg district. Sveriges Geol. Unders. Årsbok 20, no 4.

Hasegava, S. (1960) Chemical composition of allanite. Sci. Rep. Thoku Univ. Third Ser. Vol. 6, p. 331.

Kinnunen, J. and Lindsjö, O. (1967) Determination of rare earths in phosphate rock by atomic absorption flame photometry. Chemist-Analyst, Vol. 56, p. 25.

Molloy, Martin W. (1959) A comparative study of ten monazites. Am. Min., Vol. 44, p. 510.
NYKÄNEN, Osmo (1960) Explanation of the map of rocks' Geological map of Finland, Sheet 1242 Korsnäs; Geological Survey, Helsinki.

Papunen, Heikki (1968) On the barytes of Finland. C.R. Soc. géol. Finlande No 39, p. 45.

Sahama, Tн. G. (1965) Yellow apophyllite from Korsnäs, Finland. Min. Mag. 268, p. 406.

Sahama, Th. G. and Lehtinen, Martti (1967) Harmotone from Korsnäs, Finland. Min. Mag. 279, p. 444.

Tuominen, Heikki V. (1961) Geologia, Outokumpu Oy:n Korsnäsin kaivos Vuoriteollisuus - Bergshanteringen No 2, p. 26.

Wincheli, Alexander $\mathrm{N}$. and Winchell, Horace (1956) Elements of optical mineralogy, Part II, John Wiley and Sons Inc. New York.

Manuscript received, January 26, 1972. 